\title{
Protein-Polyelectrolyte Interactions
}

\section{THE CONCANAVALIN A PRECIPITIN REACTION WITH POLYELECTROLYTES AND POLYSACCHARIDE DERIVATIVES}

\author{
By R. J. DOYLE, E. E. WOODSIDE AND C. W. FISHEL \\ Department of Microbiology, University of Louisville School of Medicine, Louisville, Ky. 40202, U.S.A.
}

(Received 18 May 1967)

\begin{abstract}
1. Concanavalin A formed precipitates with polyelectrolytes such as fucoidan, RNA, heparin and bacterial lipopolysaccharides. 2. Precipitate formation also occurred between ficoll and concanavalin A. 3. Precipitate formation between concanavalin A and dextran or soluble starch was induced by the incorporation of phosphate groups into the unreactive glucans. 4. Introduction of polar groups, such as acetate, formate and phosphate, into glycogen resulted in enhanced precipitation with concanavalin A, whereas the opposite effect was noted on incorporation of hydrophobic (methyl) centres. 5. Neutral sugars and salt partially inhibited complex-formation between polyelectrolytes and concanavalin A. 6. Concanavalin A-glycogen complexes could be dissociated with $5 \%(\mathrm{w} / \mathrm{v})$ trichloroacetic acid or 44\% phenol-water. 7. Concanavalin A lost its glycogen-complexing ability after phenol treatment. 8. Evidence is presented for the existence of common binding sites on concanavalin $\mathbf{A}$ for both neutral polysaccharides and polyelectrolytes. 9. Hydrogen bonding appeared to play a major role in neutral polysaccharideconcanavalin A precipitate formation, whereas both hydrogen bonding and electrostatic forces were implicated in polyelectrolyte-concanavalin A complexformation.
\end{abstract}

The haemagglutinating activity of materials obtained from leguminous and non-leguminous plants has been recognized for many years. These plant extracts, called phytohaemagglutinins or lectins (Boyd \& Shapleigh, 1954), possess high degrees of specificity for isolated erythrocytes from various species. In addition, phytohaemagglutinins agglutinate leucocytes (Rigas \& Osgood, 1955) and stimulate the mitotic activity of lymphocytes in vitro (Nowell, 1960; Mellman \& Rawnsley, 1966). Boyd (1963) has reviewed many features of erythrocyte-phytohaemagglutinin interactions.

One of the phytohaemagglutinins, concanavalin A (isolated from jack bean), has recently received considerable attention because of its participation in precipitin-like reactions with neutral polysaccharides (Cifonelli, Montgomery \& Smith, 1956a; Manners \& Wright, 1962; Goldstein, Hollerman \& Merrick, 1965a; Goldstein, Hollerman \& Smith, $1965 b$; Goldstein \& So, 1965 ; Agrawal \& Goldstein, 1965; Goldstein \& Iyer, 1966). As a result of inhibition experiments with monomeric and oligomeric sugars it has been concluded that concanavalin A binds at the C-3, C-4 and C-6 hydroxyl positions on terminal glucopyranose or mannopyranose residues of highly branched polysaccharides (Goldstein \& Iyer, 1966; Goldstein et al. 1965b). Concanavalin $A$ also reacts with mucopolysaccharides (Cifonelli, Montgomery \& Smith, 1956b), galactan sulphate (Manners \& Wright, 1962), glycoproteins (Harris \& Robson, 1965; Nakamura \& Suzono, 1965), and bacterial lipopolysaccharides (Goldstein \& Iyer, 1966). The physicochemical properties and composition of concanavalin $A$ have been well characterized (Agrawal \& Goldstein, 1967; Olson \& Liener, 1967).

We now present evidence that concanavalin A will react with macromolecules that are devoid of terminal glucopyranose or mannopyranose residues. Moreover, inhibition experiments suggest that concanavalin A offers common binding sites both to neutral polysaccharides and to polyelectrolytes that do not contain hexoses or other neutral sugars.

\section{EXPERIMENTAL}

Chemicals. Shellfish glycogen (lot N1605), soluble starch (lot P1043), dextran (mol.wt. 80000, lot G2431) and yeast RNA (highly polymerized, lot P1199) were purchased from Mann Research Laboratories, New York, N.Y., U.S.A. Salmon sperm DNA (highly polymerized, lot 50072) was 
obtained from Calbiochem, Los Angeles, Calif., U.S.A. Ficoll (mol.wt. 400000, lot 4975) was purchased from Pharmacia Fine Chemicals, Piscataway, N.J., U.S.A. Heparin (sodium salt; lot 2031) was obtained from Nutritional Biochemicals Corp., Cleveland, Ohio, U.S.A. Fucoidan was purchased from Pierce Chemical Co., Rockford, Ill., U.S.A. Ribonuclease-resistant RNA (RNA core, lot C626) and RNA diffusate (lot CD123) were products of Worthington Biochemical Corp., Freehold, N.J., U.S.A. Bacterial lipopolysaccharides were obtained from Difco Laboratories, Detroit, Mich., U.S.A. Westphal lipopolysaccharides (45\% pnenol-water extracted) used were Escherichia coli 0128: B12 (lot134454), E. coli 0111 : B4 (lot 471289), E. coli 026: B6 (lot 134422), Salmonella abortivoequina (formerly S. abortusequi) (lot 46610), Salm. enteriditis (lot 457505), Salm. typhimurium (lot 137085), Salm. typhosa 0901 (lot 134458) and Shigella flexneri (lot 134457). Boivin lipopolysaccharides (trichloroacetic acid extracted) used were $E$. coli 026:B6 (lot 464392), Salm. enteriditis (lot 462036), E. coli 0111:B4 (lot 462737), Salm. typhosa 0901 (lot 461618), Shig. flexneri (lot 134455) and Serratia marcescens (lot 134456).

Preparation of concanavalin $A$ and glucan derivatives. A modification of the method of Agrawal \& Goldstein (1965) was used to prepare the concanavalin A. Briefly, $500 \mathrm{~g}$. of jack-bean meal (Nutritional Biochemicals Corp.) was extracted with 1.51 . of $0.5 \mathrm{M}-\mathrm{NaCl}$ at $4^{\circ}$. The suspension was clarified by centrifugation and mixed with $5 \mathrm{~g}$. of Sephadex G-200 (Pharmacia Fine Chemicals) at room temperature for $1 \mathrm{hr}$. After centrifugation, the insoluble material was washed twice with $0.5 \mathrm{M}-\mathrm{NaCl}$. Concanavalin A was removed from the Sephadex beads by mixing for $1 \mathrm{hr}$. with 1.0 M-glucose. After repeated centrifugation, the resulting supernatants were exhaustively dialysed against cold distilled deionized water. The non-diffusible material was then freeze-dried; the yield was approx. $2 \mathrm{~g}$.

Glucan phosphates were prepared by the method of Paschall (1964). Glucan acetates and formates were prepared by the methods of Roberts (1964) and Wurzburg (1964) respectively.

Fully methylated glycogen was prepared from a partially methylated derivative (Ingle \& Whistler, 1964) by the Purdie procedure as outlined by Hirst \& Percival (1965).

Concanavalin $A$ reactions with glucan derivatives and polyelectrolytes. As a screening procedure to determine reactivity with the various polymers, $4.0 \mathrm{mg}$. of concanavalin A was mixed with $0.25 \mathrm{mg}$. of polymer in $0.1 \mathrm{M}$ $\mathrm{NaCl}-0 \cdot 05 \mathrm{M}$-sodium acetate buffer, $\mathrm{pH} 5 \cdot 5$, in a total volume of $2.0 \mathrm{ml}$. Precipitate formation was measured by recording the resultant turbidity values at $450 \mathrm{~m} \mu$ on a Coleman Junior spectrophotometer. Glycogen values were calculated by the method of Cifonelli et al. (1956a) and were reproducible to within \pm 0.02 unit.

Chemical analyses. The anthrone technique of Mokrasch (1954) was used to determine sugar-containing polysaccharides. Protein was determined by the standard Lowry procedure (Lowry, Rosebrough, Farr \& Randall, 1951) and RNA by the Webb (1955) method and by u.v. absorption. Phosphorus was determined by the Fiske \& Subbarow (1929) method. Acetyl contents of glycogen acetate were determined by the procedure described by Wurzburg (1964). Formyl determinations of glycogen formate were carried out by the method of Roberts (1964). Methoxyl contents of the methylated glycogen derivatives were estimated by i.r. spectroscopy in the $3600-3200 \mathrm{~cm} .^{-1}$ region (Hirst \& Percival, 1965).

\section{RESULTS}

Reactions between concanavalin $A$ and polyelectrolytes or polysaccharides. Although the reactions between concanavalin $A$ and neutral polysaccharides have been well characterized, little is known concerning the reactivity of concanavalin A with polyelectrolytes or neutral polysaccharide derivatives. In Table 1 it is seen that several polyelectrolytes, including fucoidan, heparin, RNA and its ribonuclease-resistant core formed precipitates with concanavalin A. Conversely, DNA, RNA diffusate and CM-cellulose were not precipitated by concanavalin A.

Analysis of the individual polyelectrolytes for protein contaminants revealed that heparin, fucoidan, RNA and RNA core were free of protein. In addition, RNA, RNA core, fucoidan and heparin were found to be free of hexoses by the Dische (1962) cysteine-sulphuric acid method. Heparin gave an anthrone hexose value of $15.2 \%$, but this value can be attributed to interference by uronic acids and amino sugars (Woodside \& Kocholaty, 1960).

When neutral glucans are chemically modified, marked changes in glycogen values are observed (Table 1). Although dextran and soluble starch did not form a precipitate with concanavalin A, their respective phosphates produced significant glycogen values. In addition, the glycogen values of the acetate, formate and phosphate glycogen derivatives were higher than that of their parent glucan. In contrast, fully methylated glycogen was not precipitated with concanavalin A. A linear polysucrose, ficoll, gave a glycogen value of $0 \cdot 2$.

Attempts were made to differentiate between glycogen-binding and polyelectrolyte-binding sites on the concanavalin A molecule by noting alterations in turbidity on the addition of $0.1 \mathrm{M}$-sugars or $1 \cdot 0 \mathrm{M}$-sodium chloride. Glucose inhibited each of the polymers tested to varying degrees (Table 1). Complete inhibition by glucose was observed with glycogen, glycogen formate and ficoll. In addition, fructose and sucrose inhibited the reaction between ficoll and concanavalin A. Other experiments showed that ribose inhibited the concanavalin ARNA reaction to a somewhat lesser degree than glucose, and that 2-deoxyribose was ineffective. Similar results were observed with fucose and concanavalin A-fucoidan mixtures. In contrast, glucuronic acid did not inhibit precipitate formation when concanavalin A was mixed with heparin. Complete inhibition of precipitate formation by 1.0M-sodium chloride was observed only with heparin. Sodium chloride had no effect on glycogen 
Table 1. Concanavalin A glycogen values of glucan derivatives and polyelectrolytes, and the inhibitory effects of sodium chloride and glucose

Reaction mixtures contained $4 \cdot 0 \mathrm{mg}$. of concanavalin $\mathrm{A}, 0 \cdot 1 \mathrm{M}-\mathrm{NaCl}, 0 \cdot 05 \mathrm{M}$-sodium acetate, $\mathrm{pH} 5 \cdot 5$, and $0 \cdot 25 \mathrm{mg}$. of polysaccharide or polyelectrolyte in a total volume of $2.0 \mathrm{ml}$. D.S., degree of substitution.

\begin{tabular}{|c|c|c|c|}
\hline Glucan derivative or polyelectrolyte & Glycogen value & $\begin{array}{c}\% \text { inhibition* by } \\
1.0 \mathrm{M}-\mathrm{NaCl}\end{array}$ & $\begin{array}{c}\% \text { inhibition* by } \\
0 \cdot 1 \text { m-glucose }\end{array}$ \\
\hline CM-cellulose & 0.00 & 一 & - \\
\hline Dextran & $0 \cdot 00$ & - & - \\
\hline Dextran phosphate (D.S. 0.079) & $0 \cdot 18$ & $11 \cdot 9$ & $49 \cdot 5$ \\
\hline DNA & 0.00 & 一 & - \\
\hline Ficoll & $0 \cdot 20$ & $0 \cdot 0$ & 100 \\
\hline Fucoidan & 0.48 & 100 & $\mathbf{5 6 \cdot 4}$ \\
\hline Glycogen & $1 \cdot 00$ & $0 \cdot 0$ & 100 \\
\hline Glycogen acetate (D.S. $0 \cdot 24$ ) & $1 \cdot 08$ & $19 \cdot 1$ & $94 \cdot 1$ \\
\hline Glycogen formate (D.S. $0 \cdot 16$ ) & $1 \cdot 54$ & $12 \cdot 3$ & 100 \\
\hline Glycogen phosphate (D.S. 0.048) & $1 \cdot 42$ & $19 \cdot 5$ & $71 \cdot 1$ \\
\hline Glycogen, methylated (D.S. 1.2) & $0 \cdot 24$ & $0 \cdot 0$ & 100 \\
\hline Glycogen, fully methylated & 0.00 & - & - \\
\hline Heparin & $0 \cdot 35$ & 100 & $49 \cdot 5$ \\
\hline RNA & $0 \cdot 30$ & $46 \cdot 5$ & $51 \cdot 8$ \\
\hline RNA core & $0 \cdot 19$ & - & - \\
\hline RNA diffusate & 0.00 & - & - \\
\hline Soluble starch & $0 \cdot 00$ & - & - \\
\hline Soluble starch phosphate (D.S. 0.033) & 0.49 & $22 \cdot 4$ & $63 \cdot 0$ \\
\hline
\end{tabular}

Table 2. Chemical analysis of bacterial lipopolysaccharides and their concanavalin $A$ glycogen values

RNA and hexose values are expressed as \% of dry wt.; $\alpha$-amylase-resistant hexose values are expressed as $\%$ of total hexose content. B, Boivin-extracted lipopolysaccharide; W, Westphal-extracted lipopolysaccharide.

\begin{tabular}{|c|c|c|c|c|c|}
\hline Organism & Type & RNA & Hexose & $\begin{array}{c}\text { resistant } \\
\text { hexose }\end{array}$ & $\begin{array}{l}\text { Glycogen } \\
\text { value }\end{array}$ \\
\hline E. coli 0128: B12 & W & $40 \cdot 1$ & $15 \cdot 1$ & - & $0 \cdot 07$ \\
\hline E. coli 0111 : B4 & B & $5 \cdot 0$ & $7 \cdot 5$ & $62 \cdot 4$ & 0.00 \\
\hline E. coli 0111 : B4 & W & $14 \cdot 6$ & $20 \cdot 0$ & $50 \cdot 1$ & 0.00 \\
\hline E. coli $026: \mathrm{B} 6$ & B & $4 \cdot 8$ & $30 \cdot 6$ & $26 \cdot 9$ & 0.04 \\
\hline E. coli 026 : B6 & W & $48 \cdot 3$ & $30 \cdot 6$ & $11 \cdot 8$ & $0 \cdot 12$ \\
\hline Salm. abortivoequina & W & $0 \cdot 0$ & $19 \cdot 7$ & - & $0 \cdot 09$ \\
\hline Salm. enteritidis & B & $3 \cdot 0$ & $26 \cdot 8$ & $92 \cdot 8$ & 0.00 \\
\hline Salm. enteritidis & W & $7 \cdot 1$ & $28 \cdot 4$ & $97 \cdot 5$ & $0 \cdot 00$ \\
\hline Salm. typhimurium & $\mathbf{W}$ & $16 \cdot 4$ & $19 \cdot 0$ & - & $0 \cdot 09$ \\
\hline Salm. typhosa 0901 & B & $17 \cdot 8$ & $20 \cdot 3$ & $76 \cdot 2$ & $0 \cdot 00$ \\
\hline Salm. typhosa 0901 & W & $12 \cdot 1$ & $27 \cdot 3$ & $74 \cdot 1$ & $0 \cdot 00$ \\
\hline Shig. flexneri & $\mathbf{B}$ & $4 \cdot 0$ & $37 \cdot 4$ & $96 \cdot 1$ & $0 \cdot 80$ \\
\hline Shig. flexneri & W & $13 \cdot 8$ & $41 \cdot 6$ & $89 \cdot 0$ & $1 \cdot 34$ \\
\hline Serratia marcescens & B & $4 \cdot 0$ & $13 \cdot 4$ & $61 \cdot 4$ & 0.00 \\
\hline
\end{tabular}

and ficoll. Partial inhibition of precipitate formation by $1.0 \mathrm{M}$-sodium chloride was observed when concanavalin A was mixed with dextran, glycogen and starch phosphates, glycogen acetate and formate, fucoidan and RNA.

Concanavalin A-bacterial lipopolysaccharide reactions. Of the numerous bacterial lipopolysaccharide preparations listed in Table 2 , only a limited number were found to be precipitated with concanavalin A. These included $E$. coli 0128:B12 (Westphal lipopolysaccharide), $E$. coli 026:B6 (Boivin and Westphal lipopolysaccharide), Salm. abortivoequina (Westphal lipopolysaccharide) and Shig. flexneri (Boivin and Westphal lipopolysaccharide); only the last two gave rise to relatively high glycogen values. 


\section{Table 3. Dissociation of the concanavalin A-glycogen complex by trichloroacetic acid-ethanol and phenol-water}

Results are expressed as \% of total hexose or protein and each represents the average of four determinations. The phenol-water system contained $25 \mathrm{mg}$. of concanavalin A dissolved in $0 \cdot 25 \mathrm{M}-\mathrm{NaCl}$ and $10 \mathrm{mg}$. of glycogen.

Trichloroacetic acid-ethanol partitioning

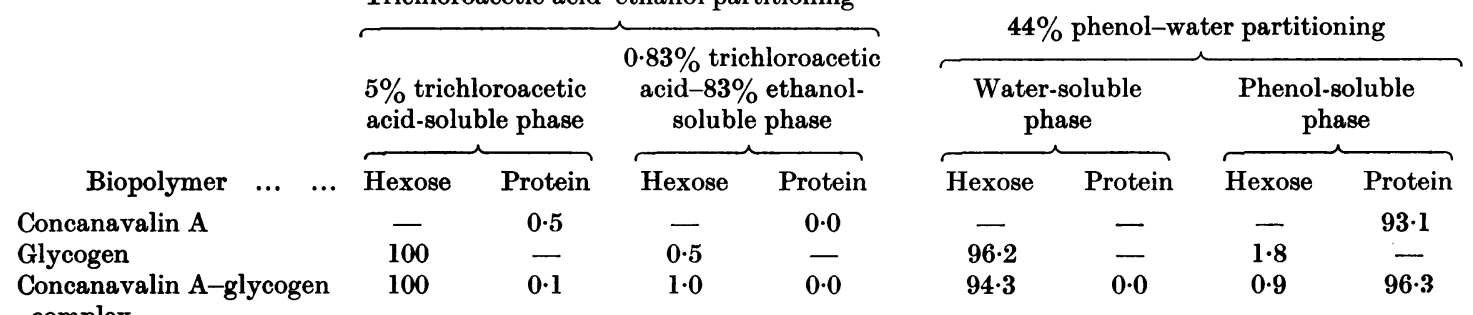

These commercially available lipopolysaccharide preparations were not subjected to additional fractionation schemes that have been used to partially remove RNA and homopolysaccharides associated with lipopolysaccharide fractions (Westphal et al. 1964). With respect to the RNA associated with the various fractions, Table 2 does not reveal any correlation between the RNA content and the degree of concanavalin A interaction. Similarly, although some of the preparations contained homopolysaccharides, as evidenced by the partial amylolytic hydrolysis of the total hexose contents (Table 2), no correlation exists between the homopolysaccharide (glycogen or starch or both) present in the fractions and the positive concanavalin A reactions. Protein analyses of the Boivin and Westphal endotoxins revealed that the former contained 2-40 times as much protein contaminant as the latter (Woodside, Frick \& Fishel, 1967).

Where both the Boivin and Westphal preparations (E. coli 026:B6 and Shig. flexneri, Table 2) reacted with concanavalin $A$, the phenol-extracted lipopolysaccharide elicited higher glycogen values. In these instances, the more reactive Westphal fractions contained higher amounts of RNA and amylase-endotoxin-sensitive homopolysaccharides than the corresponding Bovin lipopolysaccharide. Precipitate formation between concanavalin $\mathrm{A}$ and Shig. flexneri lipopolysaccharides was inhibited by approx. $15 \%$ by $1.0 \mathrm{M}$-sodium chloride and by $75 \%$ by $0 \cdot 1 \mathrm{~m}$-glucose.

Dissociation of concanavalin A-polysaccharide complexes. Recent reports concerning dissociation of protein-polysaccharide complexes (Pusztai, 1966a; Loyter \& Schramm, 1962) stimulated attempts to inhibit and partition concanavalin A-polysaccharide complexes. From the data of Fig. 1, it is seen that urea inhibited the reactions of concanavalin A with glycogen, yeast RNA and Shig. flexneri lipopolysaccharide. In addition,

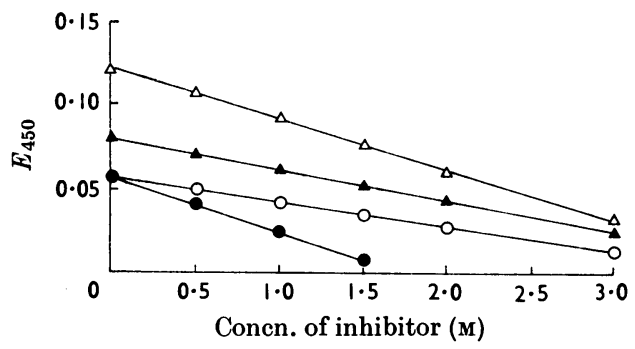

Fig. 1. Inhibition of the concanavalin A-polysaccharide precipitin reaction with urea and guanidine hydrochloride. Boivin lipopolysaccharide from Shig. flexneri (0.25 mg.) + urea $(\triangle)$; yeast RNA (1.0mg.) + urea $(\Delta)$; glycogen $(0 \cdot 2 \mathrm{mg})+$. urea $(O)$; glycogen $(0 \cdot 2 \mathrm{mg}$. $)+$ guanidine hydrochloride (๑). Reaction mixtures contained $4.0 \mathrm{mg}$. of concanavalin $A$ and the indicated concentrations of polysaccharide and inhibitor in a total volume of $4.0 \mathrm{ml}$.

lower concentrations of guanidine hydrochloride were required to inhibit glycogen-complex formation with concanavalin A. Other experiments showed that guanidine hydrochloride similarly inhibited the reaction with RNA and Shig. flexneri lipopolysaccharide. Of particular significance are the low concentrations of urea required for inhibition and the correspondingly lower guanidine hydrochloride concentrations needed for the same degree of inhibition of glycogen-concanavalin A reactions.

Dissociation of concanavalin A-glycogen complexes can be accomplished by either $5 \%$ (w/v) trichloroacetic acid or $44 \%$ phenol-water partitioning (Table 3). Treatment of the complexes with $5 \%$ $(w / v)$ trichloroacetic acid resulted in the recovery of the protein as a trichloroacetic acid-insoluble precipitate, and glycogen was recovered from the trichloroacetic acid-soluble phase by the addition of 5 vol. of aq. $95 \%(\mathrm{v} / \mathrm{v})$ ethanol. With phenolwater partitioning, the concanavalin $A$ was 
recovered from the phenol phase by methanolsodium acetate precipitation of the protein. The glycogen remained soluble in the aqueous phase. After phenol-water partitioning, it was noted that the recovered protein fractions were not capable of eliciting the characteristic precipitin-like reactions with glycogen.

\section{DISCUSSION}

The results of these studiesshow that the precipitin reactions between concanavalin $A$ and various macromolecules are complicated. It is obvious that many biopolymers that do not have highly branched structures or terminal hexose moieties readily form precipitates with concanavalin A. For example, RNA, fucoidan and starch phosphate would not be expected to react with concanavalin $A$ if reactivity depended upon branching and hexose termini. Thus the presence of highly charged groups, such as sulphate or phosphate, appears to induce reactivity with concanavalin $A$, as is seen with the dextran and soluble starch phosphates. These results may afford a partial explanation for the discrepancies noted in amylopectinconcanavalin A interactions (Manners \& Wright, 1962; Goldstein et al. 1965a). Since some amylopectin preparations contain phosphate and exhibit polyelectrolyte characteristics (Banks \& Greenwood, 1963), it is possible that, in those instances where amylopectin-concanavalin A complexformation was observed, phosphate may have made the amylopectin reactive. Similarly, although neutral galactans were incapable of precipitating with concanavalin A (Goldstein et al. 1965a), the reactivity of galactan sulphate (Manners \& Wright, 1962) may depend on the presence of sulphate.

Macromolecules can interact to form complexes via many different mechanisms. Antigen-antibody complexes are thought to be stabilized by co. operative electrostatic, hydrogen-bonding and hydrophobic-bonding forces (for review see Singer, 1965). Although concanavalin A reacts with numerous polysaccharides and polyelectrolytes to form complexes, little effort has been directed to a better understanding of the forces responsible for complex-formation. The results of this study indicate that (1) electrostatic forces are not prevalent in concanavalin $\mathrm{A}$-neutral polysaccharide complex-formation; (2) concanavalin A-polyelectrolyte complex-formation depends partially on electrostatic forces and partially on other forces that may include hydrogen and hydrophobic bondings. Because neutral sugars inhibited neutral polysaccharide (glycogen and ficoll) precipitate formation with concanavalin $\mathrm{A}$ and to a lesser degree polyelectrolyte-concanavalin A precipitate formation, it is possible that neutral polysaccharides and polyelectrolytes bind to the protein at common sites. In addition, neutral glucan and macroion precipitate formation with concanavalin $\mathbf{A}$ was inhibited by the neutral protein denaturants, urea and guanidine hydrochloride, which suggests that common sites on the protein may have been affected.

Urea and guanidine hydrochloride are well known for their properties of altering the conformations of proteins. Recent studies indicate that urea-class compounds hydrogen-bond directly to proteins (Robinson \& Jencks, 1965). Earlier it was thought that urea-protein interactions were mediated through hydrophobic forces (Wetlaufer, Malik, Stoller \& Soffin, 1964). It might be inferred that the inhibition of concanavalin A-glucan or concanavalin A-polyelectrolyte precipitate formation with urea or guanidine hydrochloride was brought about by a disruption of hydrogen bonds. However, dissociation of concanavalin $\mathbf{A}$ into non-reactive sub-units cannot be ruled out, in view of the fact that Olson \& Liener (1967) reported the presence of protein sub-units in 8M-urea-concanavalin A solutions. Hydrogen bonds in aqueous solution between small molecules are said to be unstable (Robinson \& Jencks, 1965), although favourable entropy effects may stabilize hydrogen bonds in macromolecules (Bello, Haas \& Bello, 1966).

It is interesting that RNA reacted with concanavalin A, but DNA was unreactive. Since ribose partially inhibited precipitate formation and deoxyribose was ineffective, it would appear that a fully hydroxylated sugar moiety is necessary. However, other structural differences such as base pairing or helicity may be important. The possibility of an optimum polysaccharide or poly. electrolyte molecular weight for combination with concanavalin A cannot be overlooked. Levitski, Heller \& Schramm (1964) found that macrodextrins within certain molecular weight ranges could maximally precipitate $\alpha$-amylase. Further work on this aspect is in progress.

The heterogeneity of bacterial lipopolysaccharide preparations permits only limited interpretations of their reactivity with concanavalin A. Apparently, the presence of RNA, protein and amylase-sensitive hexoses as possible contaminants of the lipopolysaccharides does not significantly bias glycogen values, as there is no direct correlation between the extent of contamination and precipitation with concanavalin A. The unusual presence of organic phosphate (in lipopolysaccharides) does not appear to give rise to reactivity with concanavalin $\mathrm{A}$ as opposed to the starch and dextran phosphates. However, the phosphate groups could be masked by contaminants. Moreover, correction for RNA and glucan contaminants in Shig. flexneri lipopolysaccharides would not greatly lower their glycogen 
values. On this basis it would appear that Shig. flexneri lipopolysaccharides possess reactive sugar end-groups.

It was shown that $44 \%$ phenol treatment resulted in the inability of concanavalin A to bind glycogen. Under essentially identical conditions, Pusztai $(\mathbf{1 9 6 6 b})$ found that bovine serum albumin and chymotrypsinogen were stable with respect to denaturation. In addition, phenol treatment of gelatin does not alter its glucan-binding properties (Woodside, Trott, Doyle \& Fishel, 1966). In unpublished work we have shown that concanavalin $A$ is thermolabile, and thus $64^{\circ}$, required to form a single phase in the phenol treatment, resulted in the denaturation of the glycogen-binding properties of concanavalin A.

This study was supported in part by the National Science Foundation Grant GB-2691 and by the National Institutes of Health Predoctoral Training Grant 1-F1-GM-31, 110-01, to R.J.D.

\section{REFERENCES}

Agrawal, B. B. L. \& Goldstein, I. J. (1965). Biochem. J. 96, $23 \mathrm{c}$.

Agrawal, B. B. L. \& Goldstein, I. J. (1967). Biochim. biophys. Acta, 133, 376.

Banks, W. \& Greenwood, C. T. (1963). Advanc. Carbohyd. Chem. 18, 357.

Bello, J., Haas, D. \& Bello, H. R. (1966). Biochemistry, 5, 2539.

Boyd, W. C. (1963). Vox Sang, Basel, 8, 1.

Boyd, W. C. \& Shapleigh, E. (1954). Science, 119, 419.

Cifonelli, J. A., Montgomery, R. \& Smith, F. (1956a). J. Amer. chem. Soc. 78, 2485.

Cifonelli, J. A., Montgomery, R. \& Smith, F. (1956b). J. Amer. chem. Soc. 78, 2488.

Dische, Z. (1962). In Methods in Carbohydrate Chemistry, vol. 1, p. 497. Ed. by Whistler, R. L. \& Wolfrom, M. L. New York: Academic Press Inc.

Fiske, C. H. \& Subbarow, Y. (1929). J. biol. Chem. 81, 629.

Goldstein, I. J., Hollerman, C. E. \& Merrick, J. M. (1965a). Biochim. biophys. Acta, 97, 68.

Goldstein, I. J., Hollerman, C. E. \& Smith, E. E. (1965b). Biochemistry, 4, 876.

Goldstein, I. J. \& Iyer, R. N. (1966). Biochim. biophys. Acta, 121, 197.

Goldstein, I. J. \& So, L. (1965). Arch. Biochem. Biophys. 111, 407.
Harris, H. \& Robson, E. B. (1963). Vox Sang, Basel, 8, 348.

Hirst, E. L. \& Percival, E. (1965). In Methods in Carbohydrate Chemistry, vol. 5, p. 287. Ed. by Whistler, R. L. New York: Academic Press Inc.

Ingle, R. R. \& Whistler, R. L. (1964). In Methods in Carbohydrate Chemistry, vol. 4, p. 83. Ed. by Whistler, R. L. New York: Academic Press Inc.

Levitski, H., Heller, J. \& Schramm, M. (1964). Biochim. biophys. Acta, 81, 101.

Lowry, O. H., Rosebrough, N. J., Farr, A. L. \& Randall, R. J. (1951). J. biol. Chem. 193, 265.

Loyter, A. \& Schramm, M. (1962). Biochim. biophys. Acta, 65, 200.

Manners, D. J. \& Wright, A. (1962). J. chem. Soc. p. 4592,

Mellman, W. J. \& Rawnsley, H. M. (1966). Fed. Proc. 25, 1720.

Mokrasch, L. G. (1954). J. biol. Chem. 208, 55.

Nakamura, S. \& Suzono, R. (1965). Arch. Biochem. Biophys. 111, 499.

Nowell, P. C. (1960). Cancer Res. 20, 462.

Olson, M. O. J. \& Liener, I. E. (1967). Biochemistry, 6, 105.

Paschall, E. F. (1964). In Methods in Carbohydrate Chemistry, vol. 4, p. 295. Ed. by Whistler, R. L. New York: Academic Press Inc.

Pusztai, A. (1966a). Biochem. J. 99, 93.

Pusztai, A. (1966b). Biochem.J. 101, 265.

Rigas, D. A. \& Osgood, E. E. (1955). J. biol. Chem. 212, 607.

Roberts, H.J. (1964). In Methods in Carbohydrate Chemistry, vol. 4, p. 289 . Ed. by Whistler, R. L. New York: Academic Press Inc.

Robinson, D. R. \& Jencks, W. P. (1965). J. Amer. chem. Soc. 87, 2462.

Singer, S. J. (1965). In The Proteins: Composition, Structure, Formation, 2nd ed., vol. 3, p. 269. Ed. by Neurath, H. New York: Academic Press Inc.

Webb, J. (1956). J. biol. Chem. 221, 635.

Westphal, O., Beckmann, I., Hämmerling, U., Jann, B., Jann, K. \& Lüderitz, O. (1964). In Bacterial Endotoxins, p. 1. Ed. by Landy, M. \& Braun, W. Newark: Rutgers University Press.

Wetlaufer, D. B., Malik, S. K., Stoller, L. \& Soffin, R. L. (1964). J. Amer. chem. Soc. 86, 508.

Woodside, E. E. \& Kocholaty, W. (1960). Blood, 16, 1173.

Woodside, E. E., Frick, C. A. \& Fishel, C. W. (1967). Canad.J. Microbiol. (in the Press).

Woodside, E. E., Trott, G., Doyle, R. J. \& Fishel, C. W. (1966). Arch. Biochem. Biophys. 117, 125.

Wurzburg, O. B. (1964). In Methods in Carbohydrate Chemistry, vol. 4, p. 286. Ed. by Whistler, R. L. New York: Academic Press Inc. 